\title{
Frequency of various types of neoplasia in a group of acromegalic patients
}

\author{
Frequência de neoplasia de diversos tipos em \\ um grupo de pacientes acromegálicos
}

Fernanda Bolfi', Helio Amante Miot' $^{2}$, Mariangela Resende'2, Glaucia M. S. F. Mazeto', Fernando Gomes Romeiro', Fábio da Silva Yamashiro ${ }^{3}$, Vânia dos Santos Nunes'

1 Departamento de Clínica Médica, Serviço de Endocrinologia e Metabologia, Universidade Estadual Paulista (Unesp) Botucatu, SP, Brazil

${ }^{2}$ Departamento de Dermatologia e Radioterapia, Serviço de Dermatologia, Unesp, Botucatu, SP, Brazil

${ }^{3}$ Departamento de Clínica Médica, Serviço de Gastroenterologia Clínica, Unesp, Botucatu, SP, Brazil
Correspondence to: Vânia dos Santos Nunes Departamento de Clínica Médica, Faculdade de Medicina de Botucatu, Universidade Estadual Paulista

Distrito de Rubião Junior, s/n 18618-970 - Botucatu, SP, Brazil vsnunes@fmb.unesp.br

Received on Sept/18/2012 Accepted on May/23/2013

\begin{abstract}
Objective: To determine the frequency of colon cancer, primary hyperparathyroidism, thyroid tumor, and skin cancer in all acromegalic patients in follow-up at the Clinics Hospital - Botucatu Medical School, from 2005 to 2011. Subjects and methods: These patients were evaluated retrospectively for colon cancer, primary hyperparathyroidism, dermatological, and thyroid tumors. Results: Of 29 patients included at the beginning of the study, two were excluded. Among 19 patients submitted to colonoscopy, one presented colon adenocarcinoma (5\%). Thyroid nodules were present in $63 \%$ of patients, and papilliferous carcinoma was confirmed in two patients $(7,7 \%)$. Four patients were confirmed as having primary hyperparathyroidism (15\%). The most common dermatologic lesions were thickened skin $(100 \%)$, acrochordons $(64 \%)$, epidermal cysts $(50 \%)$, and pseudo-acanthosis nigricans $(50 \%)$. Only one patient presented basal cell carcinoma. Conclusion: Although a small number of acromegalic patients was studied, our findings confirm the high frequency of thyroid neoplasias and primary hyperparathyroidism in this group of patients. Arq Bras Endocrinol Metab. 2013;57(8):612-6
\end{abstract}

\section{Keywords}

Acromegaly; thyroid neoplasms; colonic neoplasms; primary hyperparathyroidism

\section{RESUMO}

Objetivo: Determinar a frequência de câncer de cólon, hiperparatireoidismo primário, tumores de tireoide e pele em todos os acromegálicos em seguimento no Hospital de Clínicas da Faculdade de Medicina de Botucatu de 2005 a 2011. Sujeitos e métodos: Esses pacientes foram avaliados retrospectivamente quanto a presença de câncer de cólon, hiperparatiroidismo primário, tumores da tiroide e pele. Resultados: Dos 29 pacientes incluídos no início do estudo, dois foram excluídos. Dentre os 19 pacientes submetidos à colonoscopia, um apresentou adenocarcinoma de cólon (5\%). Nódulos de tireoide estiveram presentes em $65 \%$ dos pacientes e carcinoma papilífero, em dois deles $(7,7 \%)$. Quatro pacientes apresentaram hiperparatireoidismo primário (15\%). A maioria das lesões de pele foram: espessamento (100\%), acrochordons $(64 \%)$, cistos epidérmicos $(50 \%)$, pseudoacantose nigricans $(50 \%)$ e apenas um paciente apresentou carcinoma basocelular. Conclusão: 0 tamanho da amostra é pequeno, mas nossos achados confirmam a alta frequência da neoplasia da tireoide e hiperparatireroidismo neste grupo de pacientes. Arq Bras Endocrinol Metab. 2013;57(8):612-6

\section{Descritores}

Acromegalia; câncer de tireoide; câncer de cólon; hiperparatireoidismo primário

\section{INTRODUCTION}

A cromegaly is a chronic disorder that results from the excess of growth hormone $(\mathrm{GH})$ which, in most cases, is caused by a GH-releasing pituitary adenoma (1-3). GH growth effects are mediated specially by the liver production of insulin-like growth factor I (IGF-I), which plays an important role in the regulation of both cell proliferation and differentiation (3). Acromegaly occurs with similar frequency in both men and women, and may happen at any age. However, it is more likely to happen on the fourth and fifth decade of life.

Acromegalic patients present a four-fold higher mortality rate compared with the overall population considering the same gender and age. This high mor- 
tality is due to cardiovascular, respiratory, or neoplastic complications that may be reversed with appropriate therapy, depending upon the stage of the disorder (4).

The correlation between $\mathrm{GH}$ and cancer was first suggested in 1950 by Moon and cols. (5). They observed a high incidence of lung, adrenal and mammary tumors in female rats chronically treated with high doses of pituitary hormones.

Studies suggest that acromegalic patients present higher risk of developing both benign and malignant tumors including the ones that affect the gastrointestinal tract, thyroid, and skin $(6,7)$. The correlation between acromegaly and prostate cancer, until the present moment, is circumstantial. However, there is a correlation between serum levels of IGF-I at the upper limit of normality and prostrate cancer in the overall population $(8,9)$.

The best correlation is the one between acromegaly and colon cancer, and that is the reason to recommend that acromegalic patients should be screened for colon cancer as soon as they are diagnosed with acromegaly, and that colon cancer international guidelines should be followed $(1,10)$.

As for the need to screen for other tumors, there is controversy in the literature. Hence, the present study aims to determine the frequency of colon neoplasias as well as other tumors, such as parathyroid and skin ones, and of thyroid nodules in a group of acromegalic patients.

\section{SUBJECTS AND METHODS}

All patients with acromegaly in follow-up at the Clinics Hospital - Botucatu Medical School from 2005 to 2011 were evaluated to be included in this study. The inclusion criteria were: acromegaly diagnosis confirmed by the detection of basal GH level higher than $0.4 \mathrm{ng} /$ $\mathrm{mL}$; nadir $\mathrm{GH}$ value after oral glucose tolerance test (OGTT) higher than $1 \mathrm{ng} / \mathrm{mL}$; high IGF-I level for the respective age and gender, and a pituitary tumor confirmed by magnetic resonance imaging (MRI). Individuals that presented conflicting results for $\mathrm{GH}$ and IGF-I (only one of them presenting an increase) were removed from the study.

These patients were retrospectively evaluated for the presence of: colon neoplasias assessed via colonoscopy, and incidental colon biopsy if any lesion was found; primary hyperparathyroidism (PHP) by means of laboratory evaluation of not only parathormone (PTH) but also serum and urinary calcium. Diagnostic criteria for PHP were: serum calcium $>10.2 \mathrm{mg} / \mathrm{dL}$ (reference value: 8.4 a $10.2 \mathrm{mg} / \mathrm{dL}$ ) and $\mathrm{PTH}>65$ $\mathrm{ng} / \mathrm{L}$, with normal kidney function. Hypercalciuria was also assessed as defined by $24 \mathrm{~h}$ urine calcium $>4 \mathrm{mg} /$ $\mathrm{kg}$; thyroid cancer via fine needle aspiration cytology (FNA) of the detected nodules found by thyroid ultrasound examination and with the following features: $\geq$ $\mathrm{l} \mathrm{cm}$, and nodules $<1 \mathrm{~cm}$ with suspicious ultrasound findings (hypoechoic nodules with irregular margins, intranodular vascular spots or microcalcifications) (11); dermatologic lesions by means of a physical examination performed by a dermatologist.

This study was approved by the FMB Research Ethics Committee (FMB-PC-271/2011).

\section{RESULTS}

Twenty-seven patients out of 29 acromegalic ones were included in this experiment (Table 1). Two patients were excluded because they started to be followed up in other facilities. All patients had baseline GH higher than $0.4 \mathrm{ng} / \mathrm{mL}$, nadir $\mathrm{GH}$ higher than $1 \mathrm{ng} / \mathrm{mL}$ after OGTT, and high IGF-I level for the respective age and gender. Among enrolled patients, 18 were women and nine were men, both genders aged between 30 and 63 years old. All patients presented clinical signs of acromegaly, and the majority of them had a macroadenoma $(89 \%)$. Only one patient presented a pituitary adenoma secreting both GH and prolactin. Regarding the management, 21 (78\%) patients were submitted to transsphenoidal surgery and a GH-releasing pituitary adenoma has been confirmed by anatomopathological study in all of them. Concerning the complementary treatment, $78 \%$ and $41 \%$ were taking respectively somatostatin analogue and cabergoline, and $26 \%$ were submitted to radiotherapy (Table 1). Three patients achieved laboratory control with the surgical procedure alone.

Among nineteen patients submitted to colonoscopy, eight showed normal results (42\%) (Table 1), one (5\%) presented a $2.0 \times 1.5 \mathrm{~cm}$ adenocarcinoma (Table 1) of the ascending colon, one presented a polypoid hamartoma of the descending colon, and the other patients presented diverticular disorder and colon adenoma ( $32 \%$ and $16 \%$, respectively).

Twenty six patients were submitted to thyroid ultrasound and nodules were detected in $17 / 26$ patients (65\%) (Table 1). Nine (37\%) acromegalic patients presented suspicious nodules and/or nodules $>1 \mathrm{~cm}$. Thus, they were submitted to FNA. Thyroid papilliferous carcinoma was confirmed in two patients (Table 1), and one patient presented Hurthle cell adenoma. 
Table 1. Clinical features and IGF1 levels at screening and diagnosis of primary hyperparathyroidism, colon and thyroid nodules, and dermatologic lesions in all included acromegaly patients

\begin{tabular}{|c|c|c|c|c|c|c|c|c|}
\hline Gender & Age & $\begin{array}{l}\text { Tumor } \\
\text { size }\end{array}$ & $\begin{array}{l}\text { IGF1 (ng/mL) } \\
\text { at diagnosis }\end{array}$ & Treatment & PHP & Colon lesions & $\begin{array}{l}\text { Thyroid nodules/ } \\
\text { FBA AP findings }\end{array}$ & Acrochordons \\
\hline $\mathrm{F}$ & 31 & Macro & 403 (RV: 115-307) & TSS, SA, Cab & No & No & No & Yes \\
\hline $\mathrm{F}$ & 37 & Micro & 667 (RV: 115-307) & SA & No & Diverticulum & Yes/NA & No \\
\hline $\mathrm{F}$ & 47 & Macro & 680 (RV: 130-354) & TSS, SA, Rad & No & Diverticulum & Colloid nodule & Yes \\
\hline M & 57 & Macro & 781 (RV: 81-225) & TSS, Rad & Yes/No surgery & NA & No & No \\
\hline $\mathrm{F}$ & 38 & Macro & 456 (RV: 115-307) & TSS, SA, Cab & No & NA & Yes/NA & Yes \\
\hline $\mathrm{F}$ & 67 & Macro & 1100 (RV: 78-278) & TSS, SA & No & No & Yes/NA & NA \\
\hline $\mathrm{F}$ & 62 & Macro & 743 (RV: 78-258) & SA, Cab & No & NA & Colloid nodule & Yes \\
\hline $\mathrm{F}$ & 31 & Macro & 894 (RV: 115-307) & TSS, SA & No & No & Yes/NA & NA \\
\hline $\mathrm{F}$ & 62 & Macro & 522 (RV: 7-212) & SA, Cab & No & No & Yes/NA & NA \\
\hline M & 58 & Macro & 884 (RV: 81-225) & TSS, SA & Adenoma & NA & Colloid nodule & Yes \\
\hline M & 48 & Macro & 663 (RV: 94-252) & TSS, SA & No & NA & Yes/NA & NA \\
\hline M & 53 & Micro & 711 (RV: 78-258) & TSS & No & Adenoma & No & NA \\
\hline $\mathrm{F}$ & 54 & Macro & 671 (RV: 94-252) & TSS & No & No & No & NA \\
\hline $\mathrm{F}$ & 52 & Macro & 1800 (RV: 87-238) & TSS, SA, Cab & No & Diverticulum & No & Yes \\
\hline $\mathrm{F}$ & 32 & Macro & 986 (RV: 55-360) & TSS, SA & No & No & Yes/NA & NA \\
\hline $\mathrm{F}$ & 52 & Macro & 553 (RV: 78-258) & $\begin{array}{l}\text { TSS, TCS, SA, Cab, } \\
\text { Rad, Peg }\end{array}$ & No & Adenoma & Hurthle adenoma & Yes \\
\hline $\mathrm{F}$ & 62 & Macro & 901 (RV: 7-212) & $\begin{array}{c}\text { AS,Cab, } \\
\text { Radiotherapy }\end{array}$ & No & Adenoma & No & No \\
\hline $\mathrm{F}$ & 60 & Micro & 529 (RV: 69-200) & SA & No & Adenocarcinoma & Yes/NA & NA \\
\hline $\mathrm{F}$ & 30 & Macro & 1216 (RV: 115-307) & TSS, SA & NA & NA & NA & NA \\
\hline $\mathrm{F}$ & & Macro & 751 (RV: 130-354) & TSS, SA, Cab, Rad & Hyperplasia & NA & Colloid adenoma & No \\
\hline M & 61 & Macro & 622 (RV: 78-258) & TSS, SA, Cab & Adenoma & Diverticulum & $\begin{array}{l}\text { Papilliferous } \\
\text { carcinoma }\end{array}$ & Yes \\
\hline M & 40 & Macro & 762 (RV: 109-284) & TSS, SA, Cab & No & NA & No & NA \\
\hline M & 48 & Macro & 634 (RV: 101-267) & TSS, SA & No & No & Colloid nodule & No \\
\hline M & 63 & Macro & 1245 (RV: 75-212) & TSS & No & Diverticulum & $\begin{array}{c}\text { Papilliferous } \\
\text { carcinoma }\end{array}$ & Yes \\
\hline M & 62 & Macro & 476 (RV: 75-212) & $\mathrm{SA}, \mathrm{Cab}$ & No & Polyps & No & NA \\
\hline $\mathrm{F}$ & 52 & Macro & 675 (RV: 94-252) & TSS, SA, Rad & No & Diverticulum & Colloid nodule & No \\
\hline $\mathrm{F}$ & 35 & Macro & 1600 (RV: 114-400) & TSS, TCS, SA, Rad & No & No & Yes/NA & Yes \\
\hline
\end{tabular}

F: female; M: male; RV: reference value; TSS: transsphenoidal surgery; TCS: transcranial surgery; SA: somatostatin analogue; Cab: cabergoline; Peg: pegvisomant; Rad: radiotherapy; NA: not applicable; PHP: primary hyperparathyroidism.

All patients were assessed for PHP, and this disease was confirmed in four individuals (Table 1). Serum calcium of these patients ranged from 10.8 to $13 \mathrm{mg} / \mathrm{dL}$; two of them were evaluated by bone densitometry showing normal results. One of them was evaluated by urinary tract ultrasound and showed evidence of kidney lithiasis. Three patients underwent parathyroidectomy with autoimplantation, and surgical treatment was not indicated in one of them. From the patients who underwent surgery, one patient was found to have parathyroid hyperplasia and the other two presented adenoma. Since PHP is correlated with acromegaly, two patients were screened for the MENI gene mutations, but no mutation was detected. Their offspring were also investigated for the presence of PHP and acromegaly. However, laboratorial investigation showed normal results.

Sixteen patients were assessed for the presence of skin lesions and the most common findings were thickened skin (100\%), acrochordons (64\%), epidermal cysts $(50 \%)$, pseudo-acanthosis nigricans $(50 \%)$, and only one patient presented basal cell carcinoma. 
All mentioned neoplasias were diagnosed either during the acromegaly diagnosis or before its biochemical control (Table 1 ).

\section{DISCUSSION}

Many studies have demonstrated that patients with acromegaly present higher risk of developing malignant and benign tumors, especially the ones in the colon. Despite the variation of polyps and cancer prevalence at this site (9-38\%) in different series (12-16), the correlation between acromegaly and tumors is frequently observed, and many studies have shown that an increase in IGF-I is correlated with an increase in the prevalence of polyps $(12,13)$, adenomas (17) and proliferation of colon epithelium cells (12).

Genetic susceptibility may play an important role in the correlation between acromegaly and cancer. In the normal intestine epithelium, deactivation of the adenomatous polyposis (APC) gene may trigger the epithelium proliferation resulting in the late appearance of adenomatous polyps. The activation of K-ras gene may give rise to dysplastic adenomatous polyps which, if associated with P-53 gene deactivation, shall result in the appearance of adenocarcinoma appearance. The exact contribution of acromegaly to the colon tumorigenesis molecular mechanisms remains unknown $(18,19)$. However, a regular colonoscopy screening is recommended at baseline in all acromegalic patients (1). In the present series, the number of cases of colon carcinoma in patients who underwent colonoscopy was $5 \%(1 / 21$ patients), a prevalence higher than the one found in the overall population (10.9-15/100,000 in men and 11.7-16/100,000 in women) (20).

Some studies have shown a higher frequency of differentiated thyroid carcinomas in acromegalic patients $(16,21,22)$ due to the increased level of GH and IGF-I. Calculated risk of thyroid cancer in these patients appears to be sixty-fold higher than in the overall population $(23,24)$. In our series, two patients presented papillary thyroid cancer $(7.7 \%)$. Despite being a retrospective study, our finding is in concordance with those of Santos and cols. (25), who showed a prevalence of $7.2 \%$ of thyroid carcinoma in a case-control study of 124 acromegalic patients. The authors concluded that acromegalic individuals should be routinely submitted to thyroid ultrasound evaluation, followed by FNA of nodules, when indicated (25).

There are few reported cases about the correlation between PHP and acromegaly, and some cases were associated with Multiple Endocrine Neoplasia type 1 (MEN 1). In this syndrome, PHP is present in 90 to $97 \%$ of patients, usually as primary manifestation and consequence of two or more parathyroid hyperplasias. $\mathrm{GH}$ is also known for increasing vitamin D activation, and this provokes hypercalciuria in $80 \%$ of the acromegaly cases (26). In our study, four patients (15\%) presented PHP with hypercalciuria and hypercalcemia, three patients had the indication for parathyroidectomy. According to the recently published Clinical Practice Guidelines for Multiple Endocrine Neoplasia Type 1 (27), they met clinical diagnostic criteria for MEN1. The MENI gene study was performed in two of them. In both, the genetic study did not identify MENI mutations. Our hypothesis is that they are MENl sporadic cases, and the mutation rates for this group is usually lower than in familial cases, ranging from $30-52 \%$ and $80-90 \%$, respectively (27).

Numerous dermatosis are correlated with excess GH and insulin resistance, which may lead to an early diagnosis of acromegaly by the finding of cutaneous alterations, such as skin thickening, macroglossy, face coarsening, acrochordons, acanthosis nigricans, epidermal cysts, and lentiginous patches, especially if they appear in an early phase. Some of the earliest signs of acromegaly are the edematous and pasty feeling described by patients, and the hyperhidrosis that is considered a marker of the activity of the disorder. Appropriate treatment and control of GH synthesis enable the reduction of cutaneous lesions $(28,29)$. Acrochordons are found in up to $45 \%$ of acromegalic patients (30), and they are correlated with insulin resistance, diabetes mellitus $(31,32)$ and dyslipidemia $(33)$, in the overall population. It is still unclear whether achrocordons directly result from excess GH and IGF-1, or if they appear as a consequence of insulin resistance and dyslipidemia caused by the disease itself. Notwithstanding, there is a correlation between the number of acrochordons and the prevalence of colon benign polyps in these patients (34), but not in the overall population (35). This observation suggests a physiopathological connection between the two issues. Acanthosis nigricans seems to be a non-specific acromegaly finding since it also occurs in diabetes mellitus, obesity, excessive use of corticosteroids, and polycystic ovary disease (36).

As the present study was performed retrospectively on a small cohort of patients, drawing significant conclusions could be questionable. However, our findings suggest a high frequency of PHP, MENl, thyroid neo- 
plasia, and skin lesions in this group of patients. Large prospective studies in comparison with the overall population in terms of age and sex are required. All patients diagnosed with these neoplasias were asymptomatic, and the diagnosis was only possible via clinical, laboratorial, or image screening. Therefore, we suggest that, apart from colon carcinoma, all acromegalic patients should have their calcium profile and thyroid ultrasound examined periodically. If PHP diagnosis is confirmed, MENI gene study should also be performed.

Disclosure: no potential conflict of interest relevant to this article was reported.

\section{REFERENCES}

1. Melmed $S$, Colao A, Barkan A, Molitch $M$, Grossman $A B$, Kleinberg $D$, et al. Guidelines for acromegaly management: an update. J Clin Endocrinol Metab. 2009;94(5):1509-17.

2. Giustina $A$, Chanson $P$, Bronstein MD, Klibanski $A$, Lamberts $\mathrm{S}$, Casanueva FF, et al. A consensus on criteria for cure of acromegaly. J Clin Endocrinol Metab. 2010;95(7):3141-8.

3. Melmed S. Acromegaly. N Engl J Med. 1990;322(14):966-77.

4. Orme SM, McNally RJ, Cartwright RA, Belchetz PE. Mortality and cancer incidence in acromegaly: a retrospective cohort study. United Kingdom Acromegaly Study Group. J Clin Endocrinol Metab. 1998;83(8):2730-4.

5. Moon HD, Simpson ME, Li CH, Evans HM. Neoplasms in rats treated with pituitary growth hormone. V. Absence of neoplasms in hypophysectomized rats. Cancer Res. 1951;11(7):535-9.

6. Kurimoto M, Fukuda I, Hizuka N, Takano K. The prevalence of benign and malignant tumors in patients with acromegaly at a single institute. Endocr J. 2008;55(1):67-71.

7. Moon HD, Simpson ME, $\mathrm{Li} \mathrm{CH}$, Evans HM. Neoplasms in rats treated with pituitary growth hormone. III. Reproductive organs. Cancer Res. 1950;10(9):549-56.

8. Rowlands MA, Gunnell D, Harris R, Vatten LJ, Holly JM, Martin RM. Circulating insulin-like growth factor peptides and prostate cancer risk: a systematic review and meta-analysis. Int $\mathrm{J}$ Cancer. 2009;124(10):2416-29.

9. Correa LL, Lima GA, Paiva HB, Silva CM, Cavallieri SA, Miranda LC, et al. Prostate cancer and acromegaly. Arq Bras Endocrinol Metabol. 2009;53(8):963-8.

10. Levin B, Lieberman DA, McFarland B, Andrews KS, Brooks D, Bond J, et al. Screening and surveillance for the early detection of colorectal cancer and adenomatous polyps, 2008: a joint guideline from the American Cancer Society, the US Multi-Society Task Force on Colorectal Cancer, and the American College of Radiology. Gastroenterology. 2008;134(5):1570-95.

11. Papini E, Guglielmi R, Bianchini A, Crescenzi A, Taccogna S, Nardi F, et al. Risk of malignancy in nonpalpable thyroid nodules: predictive value of ultrasound and color-Doppler features. J Clin Endocrinol Metab. 2002;87(5):1941-6.

12. Jenkins PJ, Fairclough PD, Richards T, Lowe DG, Monson J, Grossman A, et al. Acromegaly, colonic polyps and carcinoma. Clin Endocrinol (Oxf). 1997;47(1):17-22.

13. Colao A, Balzano A, Ferone D, Panza N, Grande G, Marzullo P, et al. Increased prevalence of colonic polyps and altered lymphocyte subset pattern in the colonic lamina propria in acromegaly. Clin Endocrinol (Oxf). 1997;47(1):23-8.

14. Terzolo M,Tappero G, Borretta G, Asnaghi G, Pia A, Reimondo G, et al. High prevalence of colonic polyps in patients with acromegaly. Influence of sex and age. Arch Intern Med. 1994;154(11):1272-6.
15. Renehan AG, Bhaskar P, Painter JE, O'Dwyer ST, Haboubi N, Varma $\mathrm{J}$, et al. The prevalence and characteristics of colorectal neoplasia in acromegaly. J Clin Endocrinol Metab. 2000;85(9):3417-24.

16. Terzolo M, Reimondo G, Gasperi M, Cozzi R, Pivonello R, Vitale $\mathrm{G}$, et al. Colonoscopic screening and follow-up in patients with acromegaly: a multicenter study in Italy. J Clin Endocrinol Metab. 2005;90(1):84-90.

17. Jenkins PJ, Besser M. Clinical perspective: acromegaly and cancer: a problem. J Clin Endocrinol Metab. 2001;86(7):2935-41.

18. Aiello M, Vella N, Cannavo C, Scalisi A, Spandidos DA, Toffoli G, et al. Role of genetic polymorphisms and mutations in colorectal cancer therapy (Review). Mol Med Report. 2011;4(2):203-8.

19. Matsubara N. Epigenetic regulation and colorectal cancer. Dis Colon Rectum. 2012;55(1):96-104.

20. Facina T. Estimativa 2012: incidência de câncer no Brasil/ Estimate/2012-cancer incidence in Brazil. Rev Bras Cancerol. [review]. 2011;57:118.

21. Gasperi M, Martino E, Manetti L, Arosio M, Porretti S, Faglia G, et al. Prevalence of thyroid diseases in patients with acromegaly: results of an Italian multi-center study. J Endocrinol Invest. 2002;25(3):240-5.

22. Popovic V, Damjanovic S, Micic D, Nesovic M, Djurovic $M$, Petakov M, et al. Increased incidence of neoplasia in patients with pituitary adenomas. The Pituitary Study Group. Clin Endocrinol (Oxf). 1998;49(4):441-5.

23. Tita P, Ambrosio MR, Scollo C, Carta A, Gangemi P, Bondanelli $M$, et al. High prevalence of differentiated thyroid carcinoma in acromegaly. Clin Endocrinol (Oxf). 2005;63(2):161-7.

24. Herrmann BL, Baumann H, Janssen OE, Gorges R, Schmid KW, Mann K. Impact of disease activity on thyroid diseases in patients with acromegaly: basal evaluation and follow-up. Exp Clin Endocrinol Diabetes. 2004;112(5):225-30.

25. Dos Santos MC, Nascimento GC, Nascimento AG, Carvalho VC, Lopes $\mathrm{MH}$, Montenegro $\mathrm{R}$, et al. Thyroid cancer in patients with acromegaly: a case-control study. Pituitary. 2012;16(1):109-14.

26. Inaba $M$, Nagasue $K$, Okuno $S$, Ueda $M$, Kumeda $Y$, Imanishi $Y$, et al. Impaired secretion of parathyroid hormone, but not refractoriness of osteoblast, is a major mechanism of low bone turnover in hemodialyzed patients with diabetes mellitus. Am J Kidney Dis. 2002;39(6):1261-9.

27. Lemos MC, Thakker RV. Multiple endocrine neoplasia type 1 (MEN1): analysis of 1336 mutations reported in the first decade following identification of the gene. Hum Mutat. 2008;29(1):22-32.

28. Melmed S. Medical progress: Acromegaly. N Engl J Med. 2006;355(24):2558-73.

29. Centurion SA, Schwartz RA. Cutaneous signs of acromegaly. Int J Dermatol. 2002;41(10):631-4.

30. Thiboutot DM. Clinical review 74: dermatological manifestations of endocrine disorders. J Clin Endocrinol Metab. 1995;80(10):3082-7.

31. Letter: Skin tags in diabetes mellitus. $\mathrm{N}$ Engl $\mathrm{J}$ Med. 1976;295(3):172-3.

32. Tompkins RR. Skin tags and diabetes. Arch Dermatol. 1977; 113(10):1463.

33. Crook MA. Skin tags and the atherogenic lipid profile. J Clin Pathol. 2000;53(11):873-4.

34. Leavitt J, Klein I, Kendricks F, Gavaler J, VanThiel DH. Skin tags: a cutaneous marker for colonic polyps. Ann Intern Med. 1983; 98(6):928-30.

35. Piette AM, Meduri B, Fritsch J, Fermanian J, Piette JC, Chapman A. Do skin tags constitute a marker for colonic polyps? A prospective study of 100 asymptomatic patients and metaanalysis of the literature. Gastroenterology. 1988;95(4):1127-9.

36. Stone OJ. Acanthosis nigricans--decreased extracellular matrix viscosity: cancer, obesity, diabetes, corticosteroids, somatotrophin. Med Hypotheses. 1993;40(3):154-7. 